\title{
Legal Protection of the Registered Trademark Owner in the Constitutive System (First to File) in Indonesia
}

\author{
Raden Murjiyanto ${ }^{1 *}$ \\ ${ }^{1}$ Faculty of Law, Janabadra University, Yogyakarta, Indonesia
}

\begin{abstract}
Since the enactment of Law Number 19 of 1992 on Trademarks that had been amended last with the enactment of Law Number 20 of 2016 on Trademarks, it applies the Constitutive System (First to File) which is a change from the old system of the Declarative System (First to Use). Therefore, the legal protection is determined by a registration. However, there are still many lawsuit cases of trademark cancellation. Based on the Constitutive System, the right is granted to the first registrant. Some cases are based on a lawsuit from a party who feels as the owner of the trademark, but registered by another party. The research study, titled Legal Protection of the Registered Trademark Owner in the Constitutive System (First to File) in Indonesia, based on the problem: the first problem is how is the form of legal protection of registered trademark owner in the Constitutive System in Indonesia? The second problem is why with the Constitutive System are there still many trademarks that have not been registered? The research method used normative research method, by reviewing the documents, court decisions and applicable legislation.
\end{abstract}

\section{Introduction and Library Review}

Trademark as a right, so it must be protected, like the right to other assets. Trademark is a property and the law serves to protect property [1]. Trademark rights need to be protected, in accordance with the concept of rights, that rights are interests which are protected by the law, while interests are the individual or group demands that are expected to be met [2].

Trademark as something that can be given rights like any other property, used as a sign on goods or services traded by the party entitled. The use of a trademark for the entitled party to a product of a trade and a service business will have an effect on the economic value, since the consumer trademark will choose a particular product or service. Michael A. Carrier says, Trademarks reduce search costs by allowing customers to ascertain the link between a product and its manufacturer without investigating the product's characteristics [3]. The trademark itself is an intellectual work as a right that needs to be protected. Intellectual property is defined as a right, the right is personal, and so the idea arises to protect it. Every work of people must be respected and entitled, so as to derive its base on property right in common, namely property rights as fundamental rights [4].

\footnotetext{
* Corresponding author: rmurjiya@yahoo.com
} 
The trademark problem in Indonesia was first stipulated in Law Number 21 of 1961 concerning Company Marks and Trade Marks promulgated on October 11, 1961, hereinafter referred to as the Trademark Law of 1961, replacing the 1912 Dutch colonial inheritance law on Industrial Property. In Law Number 21 of 1961, for the owner of the trademark if the rights want to be protected under the trademark law there is no necessity to register. As a basis, the right of the trademark is determined on the basis of first-time use, while the registering party only leads to the assumption that it is the first user, as long as there is no evidence otherwise. This system is known as the declarative registration system or the "first to use" system. There are two registration systems of the trademarks right, namely the declarative system and constitutive system. The declarative system which is also called a passive system, assumes that the registered party is the party entitled to the registered trademark as the first user [5].

Registration of the trademark with the Declarative System in Indonesia in its development is deemed to be no longer appropriate, then the enactment of Law Number 19 of 1992 on Trademark, hereinafter referred to as the 1992 Trademark Law, which applies the Constitutive Registration System (first to file) in lieu of the 1961 Trademark Law which applies the declarative registration system (Firs to Use). Furthermore, Law Number 19 of 1992 was amended by Law Number 14 Year 1997 regarding the Amendment of Law Number 19 of 1992 on Trademark, and replaced by Law Number 15 Year 2001 on Trademark, hereinafter referred to as the Trademark Law 2001, and the last is replaced by Law number 20 of 2016 on Trademarks, hereinafter referred to as the Trademark law 2016. Since the enactment of the 1992 Trademark Law with its amendments to the last by the 2016 Trademark Law, the registration system is the same, which adopts the First to File System that there is registration obligations for trademark owners who want to obtain legal protection under the Trademark Law.

In the registration of the Constitutive System (First to File), then the right to the mark is determined on the basis of registration. This registration system entitles the trademark owner to register its trademark for the first time. In other words, the right to the mark is granted to the first applicant, subject to registration marks of a trademark certificate as a strong evidence for the party entitled to the mark.

Several changes in regulations in the field of Intellectual Property, especially trademarks, have also been influenced by the existence of the Indonesian state against several international conventions such as the "The Paris Convention for Protection of Industrial Property " in Paris in 1883, which has been ratified by Presidential Decree No. 24 of 1979, and Agreement Establishing The World Trade Organization (WTO), Indonesia also ratified with Law No. 7 of 1994 [6]. The influence of a country's international relations will affect the law formation.

As a result of the influence of legal relationships that has been extensively, even beyond the borders of the state, or better known as the term globalization, the influence of the legal philosophy in shaping legal politics and legal systems of a country, can also be said as one element that affects Mindset in the formation of the law [7].

In constitutive system (First to File), the right of the trademark is determined on the basis of registration. This registration system gives the trademark owner a right to register the trademark for the first time. In other words, the right to the trademark is given to the first registrant, by being given a registration sign in the form of a trademark certificate as a strong evidence for those who are entitled to the trademark.

One of the purposes of constitutive system enforcement in trademark registration is to be able to achieve legal certainty in the law protection of registered trademark. However, since the enactment of constitutive system, with the 1992 Trademark Law, until now with 
the enactment of the 2016 Trademark law, the expected legal certainty has not been fully achieved. This can be seen from the existence of several cases of registered trademark cancellation, either by the owner who has registered the trademark, or by the party who feels as the owner of the trademark even they have not registered their trademark.

In the enforcement of a constitutive system that provides legal protection for registered trademark owners, the law still provides an opportunity for cancellation by both registered trademark owners and unregistered trademark owners who feel entitled. Some cases indicate that a trademark that has been owned and used or even has a well-known reputation, can still be registered by another party that in turn leads to a cancellation dispute.

Based on these cases, this research titled: Legal Protection of Registered Trademark Owners in a Constitutive System (First to File) in Indonesia is based on some problems: first problem is how is the legal protection of registered trademark owners in the Constitutive System in Indonesia; The second problem is why with the Constitutive System are there still many trademarks that have not been registered. The research method used normative research method, by reviewing the documents, court decisions and applicable legislation.

\subsection{Trademark Rights}

Trademark is basically a sign that serves as a distinguishing power, which distinguishes between goods or services one another. A mark that will be used as a Trademark, it must have a differentiating power function. A trademark is whereby a particular item is made, to indicate the origin of the goods, and its quality assurance so that it can be compared to similar goods made and traded by a person, or another company [8]. Based on current applicable law, Trademark Rights are derived from the grant by the state on the basis of registration, with registration of Trademark, to the registrant shall be granted an exclusive right by the state for the use of a mark which has distinguishing features.

Trademark is a sign that can indicate the identity of a good or service, which distinguishes a good or service on another produced by a person, some people or legal entities with similar goods or services belonging to others and which has sufficient power of difference, used in production and trade.

Based on article 1 point 1 of the Trademark Law of the Year 2016, trademark is a sign that can be displayed graphically in the form of pictures, logos, names, words, letters, numbers, color arrangement, in the form of 2 (two) dimensions and/or 3 (three) dimensions, sounds, holograms or combinations of two or more of them to distinguish goods and/or services produced by persons or legal entities in the goods and / or services trade. In item 5, it is stated that the Trademark Right is an exclusive right granted by the state to the owner of the Mark registered for a certain period of time by using the Mark itself or granting permission to the other party to use it. From the word .... given by the state, indicates that the right of the trademark is not created by itself, but must be registered. Similarly, legal protection is principally granted to registered trademark owners.

The granting of an exclusive right by that State, carries the consequence that to obtain such right shall be through the registration according to the mechanism or procedure specified, so that if a person wishes to obtain the Trademark right, the registration shall become compulsory. In other words, a person may obtain protection and legal recognition from the State of their trademarks; it must register to the state. That system is known as the Constitutive System or first to file.

As a consequence of the Trademark rights, not every person may use the trademarks at will. If any other person wishing to use the trademarks, they shall obtain the proper authorization, also to the trademark owner may prohibit others from using it. By such right, 
the owner of the trademark may use its own or grant permission to others to use it, subject to licensing or licensing agreements. A license is an agreement between the owner of the trademark (the licensor) and the party who will use the right (the licensee). So the Trademark License is not a transfer of Trademark right, but only the grant of permission to utilize economically the right to Trademark [9].

\section{2. Trademark Legal Protection}

Under the constitutive system, the Right to Trademark is an exclusive right granted by the State to the owner of the trademark that is registered in the General Register of Marks for a certain period of time by using the trademark itself or granting the other party permission to use it. The granting of an exclusive right (special) by that country carries the consequence that to obtain such right shall be through the application of registration according to the prescribed mechanism or procedure, so that if one wishes to obtain the right of the trademark, the registration becomes compulsory. In other words so that a person may obtain protection and legal recognition from the state of his or her trademark, it must register with the state. Such a system is known as the constitutive system or first to file.

As a part of Intellectual Property Rights (IPR), Trademark Rights are a special right. The special rights are essentially exclusive and monopolistic, exercised only by the rights owner, while others may not use them without the owner's permission [10]. As a consequence of the rights of the trademark from the constitutive system, not every person may use the mark at will, but if any other person wishing to use the trademark shall obtain the authorized license, so also the trademark right owner may prohibit others from using it. By such right, the trademark owner may use its own or grant permission to others to use it, subject to licensing or licensing agreements [9].

In the view of the pros and cons of the trademark registration system, the suggestion of a switch to the constitutive system, the main reason is for legal certainty [11]. The advantage of this constitutive system is further guarantees of the existence of legal certainty in the sense of who is registered in the General Register of Marks, and then the person is entitled to the trademark for similar goods. Likewise, in the case of proof in case of a dispute, the owner of the mark simply indicates the Trademark Registration Certificate. The trademark certificate is evidence that the person is the rightful owner of the mark concerned. With such a right system will provide legal certainty, both the certainty of rights and legal protection.

\section{Objective of the study}

The research objectives are intended to analyze the form of legal protection of registered trademark owners in the Constitutive System in Indonesia, and in connection with the enactment of the Constitutive System, there are still many trademarks that have not been registered. The conclusion can be used as a recommendation for changes in regulations in the trademark field.

\section{Methodology}

The method of this research is normative research method, by reviewing several documents, in the form of judicial decisions and applicable law, including: Law number 15 of 2001 concerning Trademarks that have been replaced, and Law number 20 of 2016 concerning Trademarks and Geographical Indications, and several Court Decisions. Data 
and information obtained will be analyzed in descriptive qualitative, so the conclusions can be scientifically justified.

\section{Discussion}

Legal protection in general can be interpreted as a protection given to legal subjects either being preventive in the form of legal norms of the rule of law in order to avoid violation of rights by other parties, as well as giving the right to legal subjects to conduct lawsuit or repressive in the form of legal effort which can be done both civil and criminal.

Legal protection granted under the law is the provisions governing: a) The duty to refuse the registration of the same trademark either in essence or in its entirety with a registered trademark of another party, including a reputable trademark; b) The civil action suit for registered owners to file a civil lawsuit against another party using its trademark without rights in the form of a claim for damages and cessation of activities related to the breach of the trademark; c) A criminal sanctioning action to a party that uses the same and substantially the same trademark in its entirety with a registered trademark of the other without the right.

It is undeniable that since the enactment of constitutive system in the registration of the trademark by the enactment of Law Number 19 of 1992 on Trademark and its amendment with Law Number 14 of 1997, which is substituted by Law Number 15 of 2001, and it is replaced by Law 20 of 2016 on Trademark, there are still many trademarks that are not registered by the owner. Based on the reality, there are many trademarks that are not registered, both trademark of goods and service. Generally, producers and traders of goods, as well as services at the beginning of their business, do not use any signs as trademarks, then in the development of their business with the intention of signaling goods or services traded using symbols or signs used as a trademark. Nevertheless, unfortunately they do not register it because the most important for them are selling goods or services that are liked by consumers. Some of them are less considering the aspect of legal protection for the use of their trademark, and even they do not care about the possibility of being imitated by others.

Based on the analysis of data and information obtained from observations, generally the factors that affect owners who use the trademark do not register their trademark are:

1. There are still provisions that provide protection for unregistered trademark owners, which are:

a. The duty to refuse registration of the trademark which is same in essence or in its entirety with any other trademark even if it is not registered (Article 21).

b. The existence of a provision that still provides protection for unregistered trademark owners, which grant the right to submit a trademark cancellation lawsuit (Article 74 paragraph 2).

2. Some parties still do not know and understand the existence of the obligation to register their trademark, as well as the functions and benefits of trademark registration, especially for the trademark owner and also for the community in determining the choice of goods or services needed.

The provision allows unauthorized trademark owners to submit a claim for the cancellation of the trademark without any conditions. It should be accompanied by terms such as the trademark is considered as a well-known trademark, or at least there is also a requirement that the registrant of the trademark is a registrant who does not have a good faith.

Basically, a trademark is a sign or an identity to distinguish between goods or services with other goods or services that are traded because trademark has a function as a tool to differentiate between goods or services one another, especially for similar goods or 
services. Therefore, people can understand and can distinguish between famous and unknown trademark. Since the trademark has a very important meaning, it is necessary to have trademark protection or trademark rights to the registered trademark holder [12].

With such sign or identity as well as a form accountable business of the actor who trades and circulates or who pursue a good or service, they should be responsible for goods or services traded. In the event of a problem with the goods or services traded, even the possibility of causing harm to other parties or consumers, it will be easy to find who the business owner is and which must be accounted for the circulation of goods or services.

For manufacturers, the trademark is used as a guarantee of the value of its production, especially regarding the quality for the wearer. As for consumers, trademarks are required to make it easier in choosing of goods [13]. Thus, the consumer society will be easier to determine the choice of goods or services needed, by knowing whom the business owner is distributing goods or to seek the services referred to, as well as the consideration for consumers in choosing goods can be indicated from the trademark concerned. It is in accordance with the function of the trademark as well as the identification and quality assurance of the goods or services that are given a trademark. As the function of the trademark is as an identifier to distinguish one company's product to the other (product identity), tools of trade promotion (means of trade promotion), quality guarantee, and the designation of the origin of goods or services produced (source of origin) [14].

Quality of goods and services generally become one of the considerations for consumers to choose goods and services needed. A survey shows that consumers have a fundamental psychological need to buy a product with quality certainty. Quality assurance makes consumers feel safe [15]. Even if there is a provision for the prohibition of the circulation of goods or services using unregistered marks, it is expected that when any goods or services have been circulated or cultivated using a trademark, the trademark must be registered and if this provision is violated, it shall be subject to strict sanctions. The strict enforcement of trademark registration obligations with the imposition of sanctions also has a positive impact on non-tax revenues, as increasing number of registered trademarks will increase state revenues, in addition to the order of administration in the trademark field.

It will be difficult to know the business actors who produce the goods or services that are traded using unregistered trademarks. Whereas if the trademark is registered, it will be easy to know who produces and distributes and also who is responsible for the goods or services traded, either by looking at their own trademark physically, or by tracing through an agency that handles the administration of trademark registration, which is director general of Intellectual Property Rights of the Ministry of Justice and Human Rights.

The trademark registration regulatory system with the Constitutive System of the Trademark Law is inconsistent, since it is still possible that unlisted trademark owners to submit cancellation for a registered trademark, even in the absence of a well-known requirement, so that the Constitutional System in the trademark registrations is not meaningful and the rights of registered trademarks become weak.

The trademark registration officer should reject the application of trademark registration previously, or that has been well-known. For people who register their trademarks, there is a legal certainty that he has the trademark right. On the contrary, for others who will use the same trademark of other similar goods or services, the Trademark office will deny their registration [16]. The trademark protection through the registration system has the objective of protecting entrepreneurs of trademark owners, consumer protection, society protection through the prevention and controlling of all forms of fraudulent competition, justice, order and legal certainty, so that if the trademark registration is contrary to the objective, it should be prevented [17]. By the positive law, arrangements in the Law through the upgrading of the Constitutive System may also provide legal certainty, by granting rights under the Law. 
Similarly, in the implementation, registered trademark owners should obtain legal certainty in terms of legal protection.

By the application of Constitutive System, which is inconsistent, it affects the trademark owners. They are unwilling to register their trademarks. It happens because even if they do not register their trademarks, they will still get the protection and they can even submit a cancellation when their trademarks are registered without rights by others.

The solution is to consistently enforce registration arrangements with constitutive systems. It means that those who obtain legal protection are only registered trademark owners in accordance with applicable laws and regulations, either in the form of the right to submit a cancellation for a registered trademark or to submit a claim for compensation as a form of civil, as well as legal effort as a form of punishment.

\section{Conclusion}

The legal protections of registered trademark owners in the Constitutive System under the provisions of the Law are the obligation of the registrant's official to deny the trademark registration which is same in essence or entirety same to the other party's trademark; the right of the trademark owner to submit a claim for the cancellation of a trademark registration by other party; the right of the registered trademark owner to submit a civil lawsuit (compensation) to other parties who use the trademark without rights; granting right to the registered trademark owner to submit a criminal complaint to other parties who use the trademark without rights.

Based on the Constitutive System, the causes of many trademarks that have not been registered are: 1) The unregistered trademarks are still given a legal protection, on the terms of rejection of registration and cancellation lawsuits that may be submitted by the unregistered trademark owners, so that trademark owners are less compelled to register their trademarks, because even they do not register it, it is still protected; 2) Some parties are still unaware of and understand the existence of trademark registration obligations, as well as the functions and benefits of trademark registration especially for trademark owners and also for the society in determining the choice of goods or services needed.

\section{References}

1. T. Slamet Kurnia, Perlindungan Hukum Terhadap Merek Terkenal di Indonesia Pasca Perjanjian TRIPs, (PT Alumni, Bandung, 2011)

2. S. Mertokusumo, Mengenal Hukum, (Liberty, Yogyakarta, 1989)

3. M. A. Carrier, Duke LJ, 54, (2000)

4. O. Hasibuan. Perlindungan Hak Ekonomi Pencipta Lagu dan Pemegang Hak Terkait di Indonesia, Desertation, (UGM, Yogyakarta, 2006)

5. E. Purwaningsih, Perkembangan Intellectual Property Richtsm Kajian hukum Terhadap Hak atas Kekayaan Intelektual dan Kajian Komparatif Hukum Paten, (Ghalia Indonesia, Bogor, 2005)

6. P. Prasetyo Hadi, Yustisia, 68, 4 (2006)

7. Y. Yuhelson, J. Euro. Res. Stud., XX, 868, (2017)

8. S. Margono, L. Hadi, Pembaharuan Perlindungan Hukum Merek, (Novirindo Pustaka Mandiri, Jakarta, 2002

9. A. Mardianto, J. D. H., 11, 3 (2011)

10. A. Sujatmiko, Perjanjian Lisensi Merek Terkenal, Desertation, (Program Pasca Sarjana Universitas Airlangga, Surabaya, 2009)

11. K. Renuy N.S, Jurnal Hukum, XIX, 92 (2011). 
12. Haryono, Jurnal Ilmiah CIVIS, II, 240 (2012)

13. H. Faradz, J. D. H. 8, 97 2008)

14. M. Abdulkadir. Kajian Hukum Ekonomi Hak Kekayaan Intelektual, (Citra Aditya, Bandung, 2001)

15. L. Rudita, Hak Kekayaan Intelektual \& Perlindungan Konsumen (Sudi Tentang Indikasi Geografis Dari Perspektif Kepentingan Konsumen), Disertation, (Program Pascasarjana Universitas Indonesia, Jakarta , 2011)

16. M. Djumhana, Djubaedillah. Hak Milik Intelektual (Sejarah, Teori dan Prakteknya di Indonesia), (PT. Citra Aditya Bakti, Bandung, 1993)

17. N. Hayati, Ragam Jurnal Pengembangan Humaniora, 11, 176 (2011) 